\title{
IDEA ASSESSMENT AND SELECTION IN PRODUCT INNOVATION - THE EMPIRICAL RESEARCH RESULTS
}

\author{
Milan Stevanović, Dorian Marjanović, Mario Štorga
}

Original scientific paper

The process of innovation takes significant resources, and therefore it is of great importance for companies to recognize the ideas with high innovation capacity as early as possible, and in a transparent manner, with the least necessary amount of expert knowledge. Current research indicates that companies often carry out the selection of ideas ad hoc or intuitively, and that only a small number of companies have defined the methods for ideas assessment and evaluation. In doing so, such problems as imprecise definition of the variables used in the evaluation process of the innovation capacities of ideas, undefined metrics and interaction variables will arise. In order to determine the practical points of view in this area, a study was conducted in the form of a survey on a representative sample of Croatian companies which have product innovation in their production program. The survey is aimed at determining what motivates companies to innovate, and the ways in which companies carry out the assessment and selection of ideas. Through a thorough study of the literature, a set of variables that are commonly used in the idea capacities assessment for product development have been defined, and the survey tried to establish the practical significance of individual variables for the participants of the process. This paper presents the results of the study.

Keywords: Innovation Management; Product Development; Front-End of Innovation; Idea Management; Idea Evaluation and Selection

Procjena i odabir ideja u procesu inovacije proizvoda - rezultati empirijskog istraživanja

Izvorni znanstveni članak

Proces inovacija zahtjeva značajne resurse, te je stoga za tvrtke od velikog značaja da na transparentan način, uz što manje potrebnog ekspertnog znanja, čim ranije prepoznaju ideje visokog inovacijskog kapaciteta. Aktualna istraživanja ukazuju da tvrtke vrlo često provode odabir ideja ad hoc ili intuitivno, te da samo manji broj tvrtki ima definirane metode za procjenu i vrednovanje ideja. Pri tome se kao problem pojavljuje neprecizna definicija varijabli koje se koriste u procesima procjene inovativnog kapaciteta ideja, te nedefinirana metrika i međusobni utjecaj varijabli. Kako bismo utvrdili praktična stajališta u ovom području, provedeno je istraživanje u obliku ankete na reprezentativnom uzorku hrvatskih tvrtki koje u svom proizvodnom programu imaju razvoj proizvoda. Anketom se pokušalo odrediti koji su motivi tvrtki za inovacije, te na koje načine tvrtke provode procjenu i odabir ideja. Temeljitim proučavanjem literature, detektiran je skup varijabli koje se najčešće koriste u procjeni kapaciteta ideja za razvoj proizvoda, te se anketom pokušao ustanoviti praktičan značaj pojedinih varijabli za sudionike procesa. U ovom radu prikazani su rezultati provedenog istraživanja.

Ključne riječi: priprema razvoja proizvoda; procjena i odabir ideja; razvoj proizvoda; upravljanje idejama; upravljanje inovacijama

\section{Introduction}

In today's aggressive and globally competitive environment, the ability to innovate is a strategic must for an organization's growth and success. Innovation as the term is often used to describe how organizations create value by developing new knowledge and/or using existing knowledge in a new way [1]. The term is often connected with a development of new products or services, but organizations can also innovate in other ways, such as through new business models, internal processes, management techniques, and organizational structures [2].

New product development is a process during which available ideas, capacities, and resources are used to create new or change an existing product $[1,3]$. The process of product innovation is usually divided into three phases: preparation of product development (PPD), new product development (NPD) and the commercialization of the products $(\mathrm{CP})[4,5,6]$. The process of preparation of product development (PPD) (with which we meet in the literature under the names Fuzzy-Front End (FFE) [7], and Front-End of Innovation (FEI) [8] includes activities that are often chaotic, unpredictable and poorly structured, and which need to be taken care of before a well-structured process of new product development (NPD) [8]. Preparation of product development (PPD), is a part of the innovation process in which, on the basis of the business strategy, market opportunities identified, a product development strategy is formed, ideas for product realization created and chosen, and concepts that will be discussed at a later stage of product development created and evaluated $[8,9]$. Preparation of product development has a large impact on the overall result of the process of product innovation [10]. It is often pointed out that the activities during the PPD are in most cases crucial to the overall success of innovation [11]. Decisions made during the PPD significantly affect (according to Belay [12] more than $80 \%$ ) the total cost of product innovation.

Commercial practice and researchers agree that during the PPD, idea management is one of the most important activities [13]. There is a view, that in the process of idea management, the ability to create a large number of ideas is crucial [14]. It is undisputed that the ability of the company to implement product and process innovation depends largely on the capacity of companies to collect a sufficient number of quality ideas [15]. Numerous models, methods and techniques that encourage creativity and idea generation have been developed, and are being developed every day [16, 17]. However the idea generation is only a part of the innovation process. Availability of creative ideas is a necessity, but it certainly cannot be considered a sufficient condition for the success of innovation [14], [18]. Equally important, if not more, is the process of assessment, evaluation and selection of ideas that will bring an important advantage for a product in the market [8]. In order to make the right decision, numerous methods of idea assessment are being developed [19], [23]. Selection of specific ideas from a set of acceptable ideas is subject to compromises, assessments and risks. The product based on the selected ideas must meet the expectations of the company, customers, and users, but 
also the engineering goals, requirements and constraints, which makes the selection process very complex. For companies it is very important that among the hundreds or even thousands of created ideas, they recognize and devote themselves to just those that are most promising, as early as possible, that the company resources are optimally used [20].

However, in practice, structured methods are often not used, and the selection of ideas is carried out in informal meetings, based on previous personal experience and intuition [21]. Decision-making at this stage of product development is made difficult because of the relatively modest level of knowledge about the product that will represent the final outcome of the process of innovation, but also because of the need for a broad knowledge of many areas that need to be analysed, such as engineering, technology, markets, economics, marketing, organization, strategy, user needs, etc. [22]. It is not surprising that often the estimation of the value of an idea is carried out ad-hoc, without pre-defined criteria.

The criteria based on which the assessment, evaluation, ranking and deciding on the involvement of certain ideas in a set of acceptable ideas is carried out, follow the strategic guidelines of the company, must facilitate the use of acceptable methods that will lead to shrinking of a set of analysed ideas and maintain the highest quality of ideas. Reducing the set of collected ideas is often impossible to carry out in a single step. The process of selection of ideas is usually carried out at multiple levels including ideas' assessment of suitability, assessment of the relevance (advantages and disadvantages) of ideas, assessment of capacity for innovation, and assessment of the efficacy of fulfilling the goals, requirements, and constraints. Unlike the primary divergent process of creating ideas, the selection process is a convergent process of seeking most valuable ideas.

There are a number of approaches and understanding what are quality and creative ideas. According to [25], a quality idea is the one that contains a minimum of three features. First, the idea should apply to the problem. Second, it should be an effective solution, and third, it should be implementable. On the basis of these three conditions, an idea may be a quality one even if it is not necessarily novel or unusual, which is often cited as a conventional basic requirement for a quality idea, i.e. an idea is creative if it has both quality and novelty (rare, unusual, uncommon). Such an idea is often applied in solving the problem, but also represents an effective and feasible new solution. Researchers can rarely agree on the definition of what each of these variables exactly means in particular, and also which metric to use to determine its value [25] in the choice between several ideas that meet the above criteria.

Following the research efforts based on cases of "good practices", in presented research authors tried, by implementation of an empirical research in Croatian companies which engaged in product innovation, to determine the opinion of the participants on the process of innovation on the criteria used in ranking the importance of ideas and specific criteria for assessing the innovation capacity of ideas. For the most of variables we defined, based on an extensive study of available literature and current knowledge, certain expectations that we compared with the data collected. In doing so, we did not have in mind to prove or refute the expected values in the logic, positivist sense, but only to have starting, comparative values in the data collection.

In the research presented in this paper, our aim was to explore the markets in which the companies participate, investigate where they usually carry out their product development, and organizational conditions that keep essential in the innovation process, find the motives for the gathering ideas, and their primary sources of ideas, i.e. how companies estimate the expected benefits from some ideas. In the survey, authors tried to determine the importance of criteria that have been assumed as essential in determining the innovation capacity of an idea, such as the criteria for assessing the acceptability and applicability of ideas and criteria for assessing the creativity and potential of ideas for innovation. Overall, the goal was to find out the measure of significance of ideas for the company in innovation process, and the way of their assessing ideas' capacity for innovation, without expanding the research variables on technical, marketing, financial, or other specific indicators.

\section{Research background and related work}

During the preparation of product development (PPD), it is common that there are multiple levels of assessment, evaluation and selection of ideas, starting with an assessment of suitability of a large number of collected ideas and continuing by successively converging towards smaller and smaller set of acceptable ideas from which to select those, whose value indicates the greatest capacity for innovation success of the product $[26,27]$ and the real ability to implement.

In the existing literature a significant number of papers can be found that deal with the processes of idea management and suggest techniques, models and methods for assessing and ranking the collected ideas [25, 28]. Initial work in the field of idea management stood out as a measure of quantity for quality, i.e. if you produce a sufficient number of ideas, there will be no problem in finding good ideas ("quantity leads to quality") [14]. Some of the following studies have confirmed this hypothesis $[29,30]$ while other studies showed the lack of correlation between the number of ideas and their quality [31] and even the existence of a negative correlation [32].

The method of valuation of ideas, their quality and creativity is the subject of research in a significant number of researchers. Part of the papers published in the period from 1990 to 2005 was systematized by Dean et al [25]. In doing so, the authors were primarily led by the way and criteria for assessing the degree of creativity of a product. Creativity is often identified as the process of creation and/or implementation of new, original concept or ideas, and it is useful to consider some of methods that have been developed to assess the creativity of a particular solution, and can be applied in the ideas' assessment. Of the 90 analysed papers, 18 suggested only a method of counting ideas, without any additional quality or creative capacity checks of ideas. In 21 papers, they selected the valuation of ideas based on estimates of only one attribute (novelty-based definition), while 51 papers 
estimate the value of creative ideas on the basis of evaluating multiple attributes (multi-attribute definition).

Based on a similar study conducted on the set of 90 papers from various fields (not just focused on the creativity of the product), Plucker and his associates [33] indicate that for the assessment of creativity of products the essential variables are: novelty and usefulness. The works that have identified a level of creativity of a solution within novelty-based definitions of creative products, the authors are usually decided on the determination of the degree of values for the novelty, rarity, and originality. In the works that are trying to determine the degree of creativity on the basis of multiattribute definitions of creative products, the authors estimate the degree of creativity trying to determine variables such as originality, usefulness, novelty, resolution, elaboration, purpose, implementation, relevance, workability, thoroughness, specificity, etc. [25].

A different approach was offered Shah et al. [34], (SVS) which suggested a heavily debated and cited method of determining the value of the process for generating ideas that includes an analytical determination of values for the four attributes: novelty, variety, quality and quantity. They tried to offer metrics eligible for engineering design, taking into account the recommendations of cognitive psychologists.

Horn and Salvendy [35] carried out the assessment of creativity in a product from the perspective of users of the product, using the variables: novelty, resolution, elaboration, synthesis, affect, and preference. Affect is the "emotional impact of product creativity", defined by terms: pleasure and arousal. Preference is the "preference for product creativity", defined through attributes: centrality (that means "the consumer's interest in creativity"), and applicability, (that means "the importance of creativity to the consumer"). The authors subsequently reduced its scheme to six constructs: novelty, resolution, emotion, centrality, importance, and desire.

Dean [25], in addition to providing a comprehensive review of the literature in the field of assessment and evaluation of creativity, also proposed a method of assessment and evaluation of creativity contained in a product based on the values of the variables: novelty (originality, paradigm relatedness), workability (acceptability, implementability), relevance (applicability, effectiveness), and specificity (implicational explicitness, completeness, clarity). In the study, [27], the authors state that "evaluating the impact and the potential of new ideas before developing it implies taking into account a wide duration scale and different public targets". In order to enable a quick overview of the collected ideas and instinctive assessment of the evaluators or experts (decision makers), the authors propose the implementation of the assessment from three aspects: technological, economical, and social. In every aspect, they propose evaluation of a large number of attributes, and the final estimated value of an idea that is essential to ranking of ideas is a sum of ratings for each of the aspects. In later works, [21] the authors point out a framework for the assessment and evaluation of the ideas in the early stages of product development through two categories of criteria: objective category (objective criteria), and subjective category (subjective criteria, feeling assessment, and instant decision). The authors define objective criteria as "measurable criteria or logical assessment", while subjective criteria are defined as "unmeasured criteria at early stage", stating that the feeling assessment is based on "subjective feeling or intuition that cannot be explained by reasons", while instant decision represents a "quick decision not explained by arguments". Objective criteria consist of the following variables: novelty, feasibility, and strategy, while the Subjective Criteria consists of: social acceptability (tractability, utility, public acceptation), and comprehensibility.

To estimate the creativity contained in a solution, Cropley and Kaufman [36] propose Creative Solution Diagnosis Scale (CSDS) of 30 variables, which are subsequently reduced to 24 variables and presented under the title Revised CSDS (RCSDS). Their five categories of variables in the CSDS method are: relevance / effectiveness, problematization, propulsion, elegance, and genesis. In the RCSDS methods, they have reduced the CSDS method to: relevance / effectiveness, novelty, elegance, genesis.

Exploring the level of creativity contained in the ideas in the process of product development, Oman et al. [19], is primarily a focus on metrics based on the work [34]. Using Comparative Creativity Assessment (CCA the authors propose the coalescence of novelty and quality into the unique value (contrary to the recommendations [34]), with the intention of reducing the influence of assessors in relation to original research. But the main contribution of this study represents the proposed MultiPoint Creativity Assessment (MPCA) method, which is unusual in that it indicates the need for the evaluation of each criterion in pairs according to the principle: positive / negative. This assessment is carried out for eight pairs of values as follows: original / unoriginal, well-made / crude, surprising / expected, ordered / disordered, astonishing / common, functional / non-functional, unique / ordinary, logical / illogical. Messerle [20] points out that during the evaluation of ideas we need to evaluate aspects of: market, customer, financial, aspect on internal and external structures, strategy, politics, and law, and suggests that the aspects reviewed and assessed the value of the ideas summarized in two variables: idea potential (idea potential, strategy fit, market potential, and economic potential), and idea mastering (technical, market, organisational, and external). Kudrowitz and Wallace [37], suggest the use of NUF methods for determining the value of ideas in the process of creating an idea based on a valuation of variables Novel, Useful, and Feasible). The authors note that a significant number of previous studies have focused on evaluating the value of the finished product (not the ideas), and are led by the primary value of the utility of targeted products.

As shown in the literature we analysed, there are a number of methods and techniques with which the authors are trying to contribute to a more effective early detection of potentially high-value ideas. Some of the methods are focused on the ideas themselves, some on the assessment of a group of ideas and results of implementation of the idea and the concept of the product, while some of the 
methods are primarily oriented towards the assessment of the value in the product. What large number of analysed methods have in common is that they are in some ways trying to find a level of creativity in the ideas through an estimate of how ideas are new or previously used in similar situations, and how they meet certain quality parameters, how strategic and acceptable the implementation is and how useful and beneficial they are for the improvement of product features. The lack of consistency in defining and determining the attribute values represented a significant aggravating circumstance in comparison of results obtained. Simultaneously, a set of attributes constantly increased. In some papers dozens of attributes appeared on which to try to estimate and quantify the creativity of an idea. The practical implementation of the set of ideas evaluation, through so many variables and attributes, and application of extensive metrics, becomes in many cases too hard and too complicated. Therefore, in the research, we have tried to determine the significance of these variables in the practical process of product innovation.

\section{Methodology}

Since it is impossible to consider the entire population which is the subject of research interest, the analysed properties are estimated based on a survey of attitudes of a number of members of the population, or sample. The sample is representative if its basic characteristics are similar to the population. The sample leads to estimates of population characteristics, and statistical methods to determine the reliability and accuracy of the estimate. For the survey it is necessary to draw up a clear and precise plan for the selection of elements in the sample. The plan includes: research objectives, statistical collection, and the frame of choice, the data to be collected and the model sample.

\subsection{Participants and questionnaire}

Participants were selected from the "Register of Business Entities" database, kept at the Croatian Chamber of Commerce. For the study, we only considered companies from certain group of activities (group Cprocessing industry, according to the national classification from 2007). The selected group consisted of 13158 active companies in 2010, with 213316 employees, of which 18,911 possessed higher education $(8,87 \%)$ [38]. A collection of 6710 companies with higher levels of business activity was selected, from which a set of 1329 companies was randomly selected. The sample was randomly chosen and was not selected according to any additional criteria.

Data collection was carried out by an online survey in late 2011 and early 2012. We sent an email to all participants of the survey with the following information: who is carrying out the research, to which project the research belongs and what are the research objectives. Respondents were supposed to activate the attached link and fill out the survey. From 1329 who received the invitation to the questionnaire, about 800 participants read the message (approximately $60 \%$ ). Of this number approximately 240 participated in some way in the survey (partially or completely filled the questionnaire), which is approximately $30 \%$ of reached recipients. After the validation of the questionnaires by the criterion of completeness, for the purposes of this study 123 completed questionnaires were accepted. The fraction of response $(f)$ for the conducted research is 0,0183 (ratio the number of sample units and units in the basic group), meaning that approximately one in 55 from the basic group filled out the questionnaire. Of the 123 collected completed questionnaires, 103 respondents had qualified results (product innovation in the last two years), so that their answers are presented in the research (the collected questionnaires provides sample with margin of error less than $9 \%$, confidence level $95 \%$, response distribution 50 $\%)$.

The questionnaire is divided into four parts, according to groups of variables, for which the attitudes of respondents were collected. At the beginning of the questionnaire, every respondent was familiarized with the way of completing the questionnaire, followed by groups of questions. The study involved four groups of variables: (1) the variables on the state of the company and how to improve the product development; (2) variables on how to come up with ideas for product development; (3) variables on the method of assessing the value of ideas; (4) variables about the company and its market orientation. These four groups containing a total of 106 variables grouped into 35 questions to which respondents gave their answers. The conceptual model of research is shown in the following figure (Fig. 1).

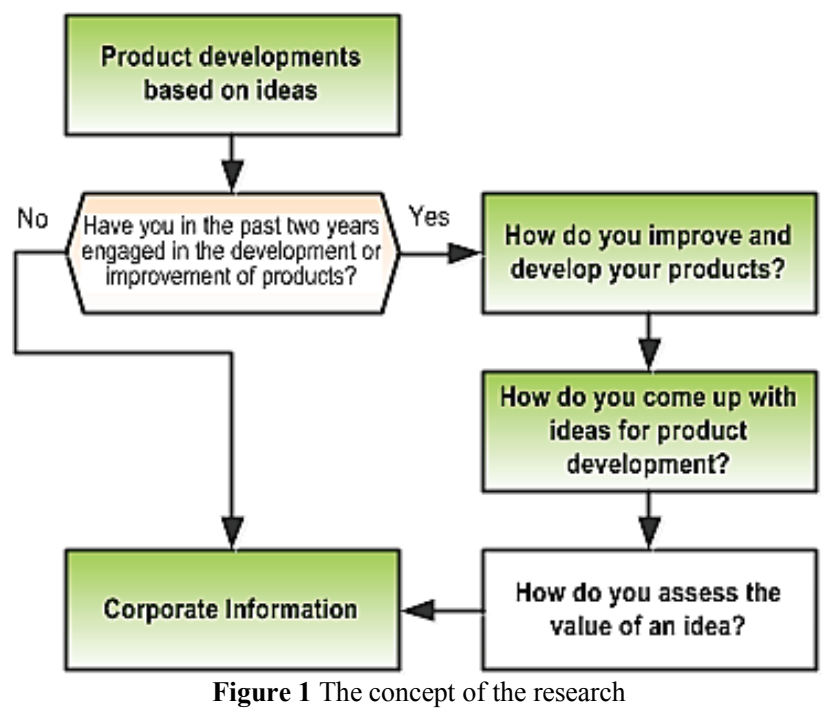

In this paper, the most important results obtained from a survey from the group 3, will be presented, with partial reference to some results from the other groups. In the table the results will be presented in two basic forms: for simple questions that respondents could answer by selecting from the available responses, the frequency and/or percentage of all responses against all the answers will be given. For more complex questions in which the respondents had to rank the value of several variables using mostly the Likert scale, the frequency and/or percentage of all responses will be given, together with some of the basic statistical measures such as: the number of elements in the series $(n)$ or the rank of variable 
according to the arithmetic mean of the results $(R)$, and standard deviation $(S D)$.

\section{Results of empirical research}

The condition for participation in the study: Only companies that were in the previous two years pursuing the products' innovation could participate in the study. For the above question, $84 \%$ of respondents said yes, $8 \%$ of respondents said no, while $8 \%$ of respondents said they do not have any products for innovation. Companies who declared that they were not engaged in the innovation of products were eliminated from the sample.

Markets where companies sell their products (Tab. 1): Given that the study involved only those companies that to some extent innovate, it was interesting to find out in which markets they commercialize their products. The starting expectations, based on studied literature, assumed a greater focus to innovation for companies which will compete in the stronger market competition.

Table 1 Markets in which products are sold

\begin{tabular}{|c|l|c|c|}
\hline & & No. & $\%$ \\
\hline 1 & National (Croatian) market & 89 & 72 \\
\hline 2 & Regional market (ex-YU market) & 59 & 48 \\
\hline 3 & European Union market & 60 & 49 \\
\hline 4 & Broader European market & 29 & 24 \\
\hline 5 & World market & 41 & 33 \\
\hline
\end{tabular}

*Multiple choices allowed. Respondents: 103; $S D=1,410$

More than half of the surveyed firms of different types aimed at several markets: national, regional and the EU market, while products of about a third (33\%) of the surveyed companies can be found outside of the EU market.

Where product development is conducted (Tab. 2): The development of the product is still in most cases carried out within the company. As high as $75 \%$ of small firms, $73 \%$ medium and $69 \%$ large, rely on their own development. Within the group in which the companies themselves carried out the product development $23 \%$ were large enterprises and $12 \%$ were medium. In total, 73 $\%$ of companies developed within the company, $11 \%$ within the group, $9 \%$, in cooperation with other companies, while only $4 \%$ do so in cooperation with educational institutions and institutes, and a negligible 2 $\%$ use the services of other companies or institutions.

Table 2 Where is product development conducted

\begin{tabular}{|c|l|c|c|}
\hline & \multicolumn{1}{|c|}{ No. } & $\%$ \\
\hline 1 & Within the company & 75 & 73 \\
\hline 2 & $\begin{array}{l}\text { Within the group, which includes the } \\
\text { company }\end{array}$ & 11 & 11 \\
\hline 3 & In cooperation with other companies & 9 & 9 \\
\hline 4 & $\begin{array}{l}\text { In collaboration with institution or } \\
\text { institutes }\end{array}$ & 4 & 4 \\
\hline 5 & In other companies or institutions & 2 & 2 \\
\hline 6 & None of above & 2 & 2 \\
\hline \multicolumn{2}{|l|}{$S D=1,134$} & 123 & 100 \\
\hline
\end{tabular}

The exclusive focus on their own resources significantly reduces innovation capacity and certainly one of the important indicators of slowed innovation. Also, it is important to point out a very small proportion
(4\%) of companies that are developing products in cooperation with scientific institutions and institutes. These results are also somewhat different in relation to the expectations of a greater representation of research and educational institutions in product innovation in the companies, i.e. the greater transfer of knowledge and technology on the specified route.

Organizational assumptions for the development of products based on ideas (Tab. 3): We were interested in the strategic orientation of the respondents for innovation and organizational conditions that respondents hold essential to be able to implement innovative strategies.

Table 3 Organizational assumptions

\begin{tabular}{|c|l|c|c|}
\hline & \multicolumn{2}{|c|}{$\begin{array}{c}\text { No. } \\
\text { for development }\end{array}$} & 65 \\
\hline 2 & $\begin{array}{l}\text { The corresponding system of permanent } \\
\text { collection of ideas }\end{array}$ & 41 & 40 \\
\hline 3 & An appropriate management of ideas & 3 & 31 \\
\hline 4 & $\begin{array}{l}\text { The corresponding system of upgrade of } \\
\text { ideas }\end{array}$ & 33 & 32 \\
\hline 5 & $\begin{array}{l}\text { The corresponding system of selection of } \\
\text { ideas }\end{array}$ & 36 & 35 \\
\hline 6 & $\begin{array}{l}\text { The corresponding system for } \\
\text { remuneration of idea creators }\end{array}$ & 27 & 26 \\
\hline
\end{tabular}

In their responses, the respondents highlighted as the most important prerequisite for the organization, "which are essential for the development of ideas", and then the "system of permanent collection of ideas" and "system of selection of ideas", "system validation and upgrading of ideas", "management system of ideas", and finally "reward system for the creators of ideas". Responses to some extent deviate from the expectations based on other studies [16], according to which the successful implementation of innovation reward system was better evaluated, but it is positive that the respondents have evaluated all the proposals as relatively significant, suggesting the understanding of the need to implement all assumptions into an innovation strategy of the company, and suggests the correct selection of the sample with respect to the eligibility of the respondents to express opinions in the domain of product innovation.

Table 4 Motives of companies for ideas

\begin{tabular}{|c|l|c|c|c|}
\hline & & Mean & Rang & SD \\
\hline 1 & New capabilities of technology & 5,14 & 4 & 1,54 \\
\hline 2 & New need of our customers & 5,74 & 1 & 0,97 \\
\hline 3 & New market expectations & 5,60 & 2 & 1,39 \\
\hline 4 & $\begin{array}{l}\text { The emergence of other } \\
\text { products }\end{array}$ & 4,88 & 5 & 1,55 \\
\hline 5 & Trends (stay current) & 5,18 & 3 & 1,53 \\
\hline
\end{tabular}

*Likert's scale from 1 to 7 . Respondents: 103

The motives that drive the collecting of ideas for product development (Tab. 4): When asked to assess the importance of individual motives for collecting of ideas for product development respondents stressed the needs of our customers as a key motive for collecting of ideas. After the needs, research participants stressed the importance of new expectations of the market and market trends. 
New technological possibilities, as well as the emergence of competing products, are not a big challenge for innovation according to respondents. This suggests a relatively small practical importance of innovation for business success and the focus of companies on waiting for customer orders that will encourage them to find a solution for the majority of the defined goals and working with well-known customers with whom the absence of competition created a strong cooperation. The primary goal of innovation is thus not a priority, but it certainly welcomes any idea that in the process of product development for customer orders adds a new value to an existing solution.

Sources of ideas for product innovation (Tab. 5): In order to rank the sources of ideas, we asked respondents to assess between 1 and 7 the representation of each source in their business. Based on the gathered score, we ranked the criteria. For the participants of the study, employees, according to the view that internal sources are the dominant source of ideas, are the most common source of ideas. After them, we ranked external sources of ideas, mainly customers and clients of companies and potential buyers of the product. In the fourth place are fairs and expos, and at the back are the expert groups as a source of ideas and enterprises specializing in research. In the research [24], as the most important source of ideas, they note customers (about $50 \%$ ), followed by marketing and sales $(18 \%)$ and employees $(11 \%)$. Participants in the study [39] responded similarly. After customers, they ranked internal sources, competition, sale, university, etc.

Table 5 Sources of ideas for product innovation

\begin{tabular}{|c|l|c|c|c|}
\hline \multicolumn{7}{|c|}{ Mable 5 Sources of ideas for product innovation } \\
\hline 1 & Employees of the company & 5,43 & 1 & 1,49 \\
\hline 2 & Suppliers & 3,41 & 5 & 1,43 \\
\hline 3 & Customers and clients & 5,25 & 2 & 1,21 \\
\hline 4 & Consultants & 2,42 & 8 & 1,55 \\
\hline 5 & Universities, institutes & 2,48 & 7 & 1,53 \\
\hline 6 & Research company & 1,87 & 10 & 1,33 \\
\hline 7 & Conferences, meetings & 3,35 & 6 & 1,64 \\
\hline 8 & Expert groups & 2,05 & 9 & 1,55 \\
\hline 9 & Fairs and exhibitions & 4,36 & 4 & 1,68 \\
\hline 10 & Potential buyers & 5,04 & 3 & 1,42 \\
\hline
\end{tabular}

*Likert's scale from 1 to 7 . Respondents: 103.

According to the study [40] the most important internal sources of ideas are the employees (approximately $42 \%$ ), external business partners (approximately $38 \%$ ) and customers (about $36 \%$ ). Apart from them, only consultants and competition was represented by more than $20 \%$.

Table 6 The importance of continuous collection of ideas on competitiveness

\begin{tabular}{|c|l|c|c|}
\hline & \multicolumn{1}{|c|}{ No. } & $\%$ \\
\hline 1 & $\begin{array}{l}\text { We would certainly have more } \\
\text { competitive products }\end{array}$ & 75 & 73 \\
\hline 2 & $\begin{array}{l}\text { It would create conditions for improved } \\
\text { competitiveness }\end{array}$ & 11 & 11 \\
\hline 3 & $\begin{array}{l}\text { Our products are only partially } \\
\text { dependent on ideas }\end{array}$ & 9 & 9 \\
\hline 4 & We do not need to change our products & 4 & 4 \\
\hline 5 & It would not affect our competitiveness & 2 & 2 \\
\hline
\end{tabular}

The impact of continuous collection of ideas on competitiveness (Tab. 6): For a significant number of respondents $(69 \%)$ the continuous process of collecting of ideas and ideas gathered in this way would create a presumption of a higher level of competitiveness. For 39 $\%$ of respondents a large number of ideas could certainly increase competitiveness, while $30 \%$ of respondents believe their market position is stable and assume that their products are only partially dependent on ideas.

Assessment of the expected benefits of the idea (Tab. 7): In a very high percentage (70 \%) some ideas are decided on directly by the management (owner). In $27 \%$ of the companies the department of research and development decides and in $17 \%$ it is the marketing department. In $17 \%$ of cases the evaluations of perceived usefulness of the idea are based on the impressions from the presentation.

Table 7 Assessing the benefits of the idea

\begin{tabular}{|c|c|c|c|}
\hline & & No. & $\%$ \\
\hline 1 & $\begin{array}{l}\text { This is decided by the management (the } \\
\text { owner) }\end{array}$ & 72 & 70 \\
\hline 2 & $\begin{array}{l}\text { On the basis of opinions from the } \\
\text { presentation }\end{array}$ & 17 & 17 \\
\hline 3 & $\begin{array}{l}\text { Based on the analysis of the department for } \\
\text { research and development }\end{array}$ & 28 & 27 \\
\hline 4 & $\begin{array}{l}\text { Based on the analysis of the marketing } \\
\text { department }\end{array}$ & 18 & 17 \\
\hline 5 & $\begin{array}{l}\text { Based on the data from the system for } \\
\text { evaluation }\end{array}$ & 8 & 8 \\
\hline 6 & $\begin{array}{l}\text { On The basis of assessments from hired } \\
\text { experts }\end{array}$ & 6 & 6 \\
\hline 7 & None of above & 5 & 5 \\
\hline
\end{tabular}

These results were expected, given the presumption about the poorly defined strategic framework for the development of products, which directly affects the need for the "reinterpretation" of the current strategy first-hand (of directors or owners) and at the same time prevents any allocation of responsibility to a greater number of relevant decision makers and eventual implementation of decision support systems. These results indicate to the potential problem of decision-making by unqualified or low qualified staff for the simple reason that all the necessary knowledge for making these important decisions cannot be concentrated at the level of one person. The consequence of this is avoiding the decision on the implementation of any new ideas, avoiding serious development of innovation and keeping in waiting concrete orders.

Table 8 Selection of ideas for products

\begin{tabular}{|r|l|r|r|}
\hline & \multicolumn{1}{|c|}{ No. } & $\%$ \\
\hline 1 & $\begin{array}{l}\text { Based on management's decisions } \\
\text { (owner) }\end{array}$ & 67 & $65 \%$ \\
\hline 2 & $\begin{array}{l}\text { Estimates and experiences from } \\
\text { experts }\end{array}$ & 51 & $50 \%$ \\
\hline 3 & Based on market research & 36 & $35 \%$ \\
\hline 4 & Based on existing customer orders & 41 & $40 \%$ \\
\hline 5 & $\begin{array}{l}\text { Based on the proposal of decision } \\
\text { support systems }\end{array}$ & 4 & $4 \%$ \\
\hline 6 & Based on intuition & 15 & $15 \%$ \\
\hline & *Multiple choices allowed. Respondents: 103; SD=1,489 \\
\hline
\end{tabular}


The process of selection of ideas for product development (Tab. 8): Answers to the question of how to select ideas for product development are correlated with the previous question. In this case the decision on the selection of ideas with $65 \%$ of respondents is carried out by the Administration (owner), while in $50 \%$ the selection was carried out on the basis of assessment and experience of experts.

In $40 \%$ of the respondents it was relevant customer orders, and in $35 \%$ the market needs. Decision support systems in each case are the great unknown with regard to being used by only $4 \%$ of respondents in the implementation of the selection of ideas. As with the previous question, that distribution of responses again confirms the assumption of probable lack of appropriate development and/or innovation strategies, which prevents the expansion of groups of decision makers to a larger number of qualified participants.

Risks are analysed when selecting ideas (Tab. 9): A number of risks hampers the implementation of some ideas. A very significant number of companies highlight as the dominant risk the risk that the development process will be unprofitable (62\%). After this risk, the risk that follows is based on whether a particular product will be able to realize the idea (Technology) (37\%), and the risk that someone has already made such a product $(26 \%)$.

Table 9 The risks in choosing ideas
\begin{tabular}{|c|l|c|c|}
\hline & \multicolumn{1}{|l}{} & No. & $\%$ \\
\hline 1 & The risk that we will not be able to realize it & 38 & 37 \\
\hline 2 & $\begin{array}{l}\text { The risk that someone already made it (not } \\
\text { the first) }\end{array}$ & 27 & 26 \\
\hline 3 & $\begin{array}{l}\text { The risk that someone already knows that's } \\
\text { impossible }\end{array}$ & 7 & 7 \\
\hline 4 & $\begin{array}{l}\text { The risk of developing the idea which gives } \\
\text { the advantage to the competition }\end{array}$ & 22 & 21 \\
\hline 5 & $\begin{array}{l}\text { The risk that the development process will } \\
\text { be unprofitable }\end{array}$ & 64 & 62 \\
\hline 6 & Other risks & 9 & 9 \\
\hline
\end{tabular}
*Multiple choices allowed. Respondents: $103 ; S D=1,745$

Based on the collected responses, it can be concluded that the largest integrated risk is the risk of financial failure, and the risk that due to the large number of unknowns during the preparation of product development some important situations will be missed which will later lead to failure, which in times of a significantly reduced market can be disastrous for the survival of the company. Applying of the scientific approaches to such problems can significantly reduce the high level of uncertainty at this stage of development.

Table 10 Criteria for ideas' innovation capacity

\begin{tabular}{|c|l|c|c|c|}
\hline & & Mean & Rang & SD \\
\hline 1 & Acceptability & 3,82 & 2 & 0,97 \\
\hline 2 & Applicability & 4,43 & 1 & 0,77 \\
\hline 3 & Creativity & 3,51 & 3 & 1,10 \\
\hline 4 & Potentiality & 3,27 & 4 & 1,19 \\
\hline \multicolumn{4}{|l}{ *Likert's scale from 1 to 5. Respondents: 103. }
\end{tabular}

Ranking criteria for assessing the innovation capacity of ideas (Tab. 10): Based on a broad analysis of the subject literature, we selected four criteria: acceptability of ideas, applicability of ideas, creativity of ideas, and idea's potentiality, and we asked respondents to rate the importance of the mentioned criteria for innovation capacity of ideas.

Contrary to the assumption of the great importance of creativity for innovation capacity of ideas, respondents proposed criteria ranked differently.

These responses are correlated with previous answers on insufficient innovation orientation of participants, i.e. the primarily development and production orientation, and innovative orientation only in part and primarily through small improvements in existing products (incremental innovation). The choice of applicability of ideas as the most important factor for assessing the innovation capacity of ideas points to a significant lack of ideas, and the lack of system for storage and processing of collected ideas, as the processing retains only acceptable and useful ideas.

Ranking of criteria for assessing the acceptability of ideas (Tab. 11): Based on the analysis of literature, we assumed criteria that have a significant impact on the risk assessment of the acceptability of ideas, and we asked respondents to evaluate the proposed criteria. Contrary to the assumption that the business acceptability of ideas, in the existing business conditions, will be the best evaluated, respondents expressed the view that strategic acceptability of ideas is the most important.

Table 11 Criteria for acceptability of an idea

\begin{tabular}{|c|l|c|c|c|}
\hline & & Mean & Rang & SD \\
\hline 1 & Business strategy & 4,03 & 1 & 0,91 \\
\hline 2 & Commercial viability & 3,77 & 4 & 1,08 \\
\hline 3 & Available technology. & 3,81 & 3 & 1,08 \\
\hline 4 & Available resource & 3,85 & 2 & 1,12 \\
\cline { 2 - 5 } & *Likert's scale from 1 to 5. Respondents: 103.
\end{tabular}

Logistical acceptability (the existence of all the necessary resources for the realization of the idea) was ranked in second place, technological acceptability was third, and business acceptability was in the last place. Deviation from initial assumptions is partly attributed to the rational consideration of the objective conditions of the area of management of ideas and expressing a positive desired state as the most important.

Table 12 Criteria for applicability of an idea

\begin{tabular}{|c|l|c|c|c|}
\hline & & Mean & Rang & $S D$ \\
\hline 1 & Elaboration & 3,70 & 4 & 1,08 \\
\hline 2 & Feasibility & 4,32 & 1 & 0,74 \\
\hline 3 & Scalability & 3,80 & 3 & 1,02 \\
\hline 4 & Adaptability & 4,06 & 2 & 0,91 \\
\hline \multicolumn{2}{|c|}{ *Likert's scale from 1 to 5. Respondents: 103. }
\end{tabular}

Ranking of criteria for assessing the applicability of ideas (Tab. 12): Respondents were asked to evaluate the criteria for which we assumed to have a big impact in the assessment of the applicability of some ideas. With their assessments, respondents expressed the view that feasibility (practical significance) is the most important for the applicability of an idea, followed by the ability to adapt the idea and the ability to upgrade, and finally the very elaboration of the idea. This ranking partially coincides with the initial assumption, according to which it is assumed that the respondents would primarily incorporate in their product an idea that you can realize with the available logistical resources, while they would 
be substantially less interested in the introduction of new technological solutions or searching for potential suppliers or partners.

This view is correlated with the response to the question about the motives of companies for collecting ideas (Tab. 4), and with a relatively low ranked motive for the application of new technologies.

Ranking of criteria for assessing the creativity of ideas (Tab. 13): During the selection of criteria for assessing the creativity of ideas there was great confusion with regard to the great diversity of representation of criteria in the considered literature, i.e. the convergence on a few simple criteria such as novelty and quality of ideas. Therefore, we decided to avoid asking for explicit evaluation of such strong criteria. Instead, we primarily try to get the opinions of respondents on factors for which we assumed to participate in the conclusion of how new or good an idea is. In doing so, we opted for the two groups of criteria: one that we consolidated under the concept of criteria for assessing the creativity of ideas (Tab. 13) and the other under the concept of criteria for evaluation of the potential of ideas (Tab. 14).

Table 13 Criteria for creativity of an idea

\begin{tabular}{|c|l|c|c|c|}
\hline & & Mean & Rang & SD \\
\hline 1 & Originality & 3,93 & 1 & 1,14 \\
\hline 2 & Unexpectedness & 3,16 & 3 & 1,17 \\
\hline 3 & Attractiveness & 3,59 & 2 & 1,08 \\
\hline 4 & Provocativeness & 2,57 & 5 & 1,14 \\
\hline 5 & Fashionability & 2,73 & 4 & 1,23 \\
\hline
\end{tabular}

*Likert's scale from 1 to 5. Respondents: 103.

While evaluating the importance of the criteria for assessing the creativity of an idea, respondents expressed that the most important is the originality of an idea (how original it was in its formation), then the attractiveness of an idea, followed by unexpectedness, trendiness, and finally provocativeness. We believe that all of these criteria, in a way, collectively point to an entirely new and current way of looking at a specific problem in accordance with the scientific, technological and social trends (attractiveness, trendiness).

Table 14 Criteria for potentiality of an idea

\begin{tabular}{|c|l|c|c|c|}
\hline & & Mean & Rang & SD \\
\hline 1 & Novelty & 4,11 & 2 & 0,96 \\
\hline 2 & Variety & 3,72 & 4 & 0,99 \\
\hline 3 & Usefulness & 4,28 & 1 & 0,77 \\
\hline 4 & Competition & 3,91 & 3 & 0,91 \\
\hline
\end{tabular}

*Likert's scale from 1 to 5. Respondents: 103.

Ranking of criteria for assessing the innovation potential of ideas (Tab. 14): Continuing on the previous question, we have asked respondents to continue with evaluation of criteria which are considered as a group of criteria for assessing the creative potential of ideas. Respondents ranked their assessments of the proposed criteria in a way that first pointed out the usefulness of an idea, after that novelty featured in the idea, then recognisability of an idea and, lastly, the diversity of an idea. This ranking of criteria was a little surprizing because we were convinced (as was defined in the initial hypothesis) that, if not for any other reason, then at least because so much emphasis has been placed on it in recent literature, subjects will rank the novelty featured in an idea in the first place.

However, contrary to expectations, as in several previous cases, the convenience of product development for known customers and known needs of the customers, i.e. the development of products with incremental changes, dominates, for which the usefulness of an idea is more important than the degree of novelty the idea brings.

\section{Discussion}

Participants of the study represent the entire population made of market-oriented companies dealing with product innovations. A significant number of companies commercialize their products on the EU market that collected result provides with the necessary relevance. Cognition of the need for ideas in product development and the need for continuous ideas collection is not practically appropriate implemented. The products are still primarily developed for well-known customers, based on previous orders. Company employees are still the dominant source of ideas that indicates a high degree of closeness and a low level of cooperation in the product development process. At the same time, this approach limits the process of innovation to implementing those ideas that, to some extent, have been already agreed with the customer and reduce innovation in basic, incremental improvement of an existing product.

The assessment of an idea is in a number of cases related solely to the assessment of one person that indicates the lack of strategic documents related to innovation and the criteria for assessing the idea. These limit the expansion of the set of participants in the decision-making process and limit the decision-making process with the level of awareness and knowledge of a small number of participants. Respondents point out the dominant risk of failure in the market that indicates insufficient knowledge of the market and the low level of networking. In the process of evaluating ideas, participants' dominant criterion is applicability of ideas, in particular the feasibility of the idea, which indicates that new products are rarely based on the actual knowledge and new technologies. After applicability, research participants emphasized ideas acceptability as the next important criterion in the process of evaluating ideas. Doing so, the acceptability of certain ideas has been primarily assessed with the business strategy. That, again, points to a higher limitation to existing and well-known products.

For the participants creative capacity of idea and the potential for innovation the idea contains are less important criteria in the idea management process. When considering the creative capacities of ideas, the company has highest priority to the originality and attractiveness of the idea i.e. to the unexpectedness of the idea. In considering the potential for innovation, the most important indicators for the companies are usefulness of some ideas and novelty that idea contains.

Respondents' answers indicate insufficient implementation of management in product development process, at an early stage of development and respectively insufficient implementation of idea management. The risk of market failure significantly limits the application of 
ideas whose realization requires new knowledge and new technologies. Therefore, participants' consciousness about the need to change the current situation is not surprising at all.

\section{Conclusion and future work}

The success of product innovation significantly depends on a set of ideas driving the development of the product, but the set of ideas existence by itself is not enough. In order to make a transparent decision and idea selection, it is necessary to determine the level of quality of each idea, and to group and rank ideas in a transparent manner. Also, it is necessary to analyse how ideas fit into the strategic guidelines, how innovative they are, and how effectively they can fulfil the requirements, objectives, and constraints.

Therefore, we explore in detail how previous researches had evaluated the innovative capacity of an idea in order to upgrade the practical knowledge based on experience of the survey participants actually engaged in product innovation. After that, we offer, on the basis of extensive study of available literature, a set of criteria for the assessment of the innovative capacity of ideas and a set of attributes describing each criterion. We discussed the impact of acceptability, applicability, creativity and potentiality of ideas on their innovation capacity. Doing so, we were interested in their practical significance in the process of ideas evaluation so we asked survey participants to rank defined criteria and the associated attributes.

The collected data gave us clearer and broader insight into both, the field of ideas management and the field of assessment, evaluation and selection methods of ideas for product development. The results obtained by the survey are useful as examples of good practice, for practical application, as well as for improvement methods of ideas assessment, evaluation, and selection in order to combine scientific knowledge with practical possibilities and needs of the users.

The current way of ideas assessment and evaluation, which, according to the respondents' views and opinions, largely relies on personal competence and abilities of individuals, is not efficient enough. New product development is primarily determined by customer orders and significantly limits the innovation potential of companies. Furthermore, the product development is primarily based on ideas that can be easily implemented, and are useful for the particular customer order. The degree of entirely new products development that requires new knowledge and new technologies is quite low.

There is a high degree of consensus and knowledge among respondents about the need to transform the existing situation. The innovation potential of the company is limited, because of insufficiently implemented "organization for innovation", and is qualitatively underdeveloped.

For the innovative capacity improvements it is necessary to primarily develop key drivers of innovation such as: leadership, innovative culture, and business strategy. The need for a continued strengthening of elements that constitute an innovative environment should be noted. This includes: focus on consumers and customers, teamwork, cooperation, strengthening of resources, business communications, the ability to select ideas that have the greatest innovation capacity, the ability to recognize and reward creative person, freedom for innovation, the ability to measure the results of innovation, encouraging the continuous creation of both large and small ideas, the culture of tolerance, and an organizational structure that encourages innovation, diversity. As a part of overall efforts to change the situation in the field of innovation, through the strengthening of the above elements, it is necessary to make a bigger step forward, from incremental to radical innovation.

\section{Acknowledgements}

Presented research was founded by project "Models and methods of knowledge management in product development" supported by the Ministry of Science, Education, and Sports of the Republic of Croatia, and MinMED project (www.minmed.org) funded by Croatian Science Foundation.

\section{References}

[1] Stevanović, M.; Marjanović, D.; Štorga, M. Idea Relevancy Assessment in Preparation of NPD. // Proc. of the $19^{\text {th }}$ International Conf. of Eng. Design, Sungkyunkwan University, Seoul, Korea, 2013.

[2] American Management Association, the quest for innovation, A Global Study of Innovation Management 2006-2016, New York, www.amanet.org,(08.10.2014)

[3] Feyzioglu, O.; Buyukozkan, G. Evaluation of New Product Development Project using Artificial Intelligence and Fuzzy Logic. // World Academy of Science, Engineering and Technology. 11(2005), pp. 363-369.

[4] Koen, P.; Ajamian, G. et al. Providing clarity and a common language to the "Fuzzy Front End". // ResearchTechnology Management. 44(2001), pp. 46-55

[5] Alves, J.; Marques, M.; Saur, I.; Marques, P. Creativity and Innovation through Multidisciplinary and Multisectoral Cooperation. // Creativity and innovation management. 16, 1(2007), pp. 27-34. DOI: 10.1111/j.14678691.2007.00417.x

[6] Bullinger, C. Innovation and Ontologies, Structuring the Early Stages of Innovation Management, $1^{\text {st }}$ Edition, Gabler, GWV Facherverlage Gmbh, Wiesbaden, 2008.

[7] Smith, P; Reinertsen, D. The Strategist's Role in shortening Product Development. // The Journal of Business Strategy. July/August, (1991), pp. 18-22.

[8] Koen, P. The Fuzzy Front End for Incremental, Platform, and Breakthrough Products, In Kahn, K. B. (ed.), The PDMA Handbook of New Product Development, John Wiley \& Sons, New York, (2004), pp. 81-91. DOI: 10.1002/9780470172483.ch6

[9] Stevanović, M. Idea Selection in Product Development. // PhD Thesis, FSB, Zagreb, 2012.

[10] Dewulf, K. Sustainable Product Innovation: The Importance of the Front-End Stage in the Innovation Process, Intech, Open science / Open mind, 2013.

[11] Reid, S.; De Brentani, U. The Fuzzy Front End of New Product Development for Discontinuous Innovations: A Theoretical Model. // The journal of Product Innovation Management. 21, 3(2004), pp. 170-184. DOI: 10.1111/j.0737-6782.2004.00068.x

[12] Belay, A. M. Design for Manufacturability and Concurrent Engineering for Product Development. // 
International Journal of Social and Human Sciences, 3(2009).

[13] Dornberger, U.; Suvelza, A. Managing the Fuzzy Front End of Innovation, First edition, International SEPT Program of the Leipzig University, September 2012.

[14] Rietzschel, E.; Nijstad, B.; Stroebe, W. The selection of creative ideas after individual idea generation: Choosing between creativity and impact. // British Journal of Psychology. 101, (2010), pp. 47-68. DOI: 10.1348/000712609X414204

[15] Aagaard, A. Idea management in facilitation of pharmaceutical front end innovation, Institute of leadership and strategy, University of Southern Denmark, 2008.

[16] Glassman, B. Improving idea generation and idea management in order to better manage the fuzzy front end of innovation. // $\mathrm{PhD}$ Thesis, Purdue University, West Lafayette Indiana, 2009.

[17] Bassiti, L.; Ajhoun, R. Toward an Innovation Management Framework: A Life-Cycle Model with an Idea Management Focus. // International Journal of Innovation, Management and Technology. 4, 6(2013), pp. 551-559. DOI: 10.7763/IJIMT.2013.V4.460

[18] West, M. Sparkling fountains or stagnant ponds: An integrative model of creativity and innovation implementation in work groups. // Applied Psychology: An International Review. 51, (2002), pp. 355-424. DOI: 10.1111/1464-0597.00951

[19] Oman, S.; Tumer, I.; Wood. K.; Seepersad, C. A comparison of creativity and innovation metrics and sample validation through in-class design projects. // Research in Engineering Design. 24, 1(2013), pp. 65-92. DOI: 10.1007/s00163-012-0138-9

[20] Messerle, M.; Binz, H.; Roth, D. Elaboration and assessment of a set of criteria for the evaluation of product ideas. / International conference on engineering design, ICED13, Sungkyunkwan University, Seoul, Korea, 2013.

[21] Ferioli, M.; Dekoninck, E.; Culley, S.; Roussel, B.; Renaud, J. Understanding the rapid evaluation of innovative ideas in the early stages of design. // Int. J. Product Development. 12, 1(2010), pp. 67-83. DOI: 10.1504/IJPD.2010.034313

[22] Ozer, M. What Do We Know About New Product Idea Selection, Center for Innovation Management Studies (CIMS), Raleigh, North Carolina, 2002.

[23] Rebernik, M.; Bradač, B. Module: Idea evaluation - Idea evaluation methods and techniques, Ekonomsko poslovna fakulteta, Univerza v Mariboru, 2008.

[24] Riederer, J. P.; Baier, M.; Graefe, G. Innovation Management - An Overview and some Best Practices, CLAB Report, Vol. 4, No. 3, (2005), pp. 1-58

[25] Dean, D.; Hender, J.; Rodgers, T.; Santanen, L. Identifying Quality, Novel, and Creative Ideas: Constructs and Scales for Idea Evaluation. // Journal of Association for Information Systems. 7, 10(2006), pp. 646-699.

[26] Cooper, R. The stage-gate idea-to-launch process-update, what's new and NexGen systems. // J. Product Innovation Management. 25, 3(2008), pp. 213. DOI: 10.1111/j.15405885.2008.00296.x

[27] Ferioli, M.; Roussel, B.; Renaud, J.; Truchot, P. Evaluation of the potential performance of innovative concepts in the early stages of the new-product development process (NPDP). // International design conference - Design 2008, Dubrovnik-Croatia, 2008.

[28] Brown, D. Let's not get too creative. // Design computing and Cognition DCC'14. J. S. Gero (ed), Springer, 2014.

[29] Diehl, M.; Stroebe, W. Productivity Loss in Brainstorming Groups: Toward the Solution of a Riddle.
// Journal of Personality and Social Psychology. 53, 3(1987), pp. 497-509. DOI: 10.1037/0022-3514.53.3.497

[30] Gallupe, R.; Dennis, A.; Cooper, W.; Valacich, J. "Electronic Brainstorming and Group Size. // Academy of Management Journal. 35, 2(1992), pp. 350-369. DOI: $10.2307 / 256377$

[31] MacCrimmon, K.; Wagner, C. Stimulating Ideas through Creativity Software. // Management Science. 40, 11(1994), pp. 1514-1532. DOI: 10.1287/mnsc.40.11.1514

[32] Connolly, T.; Jessup, M.; Valacich, J. Effects of Anonymity and Evaluative Tone on Idea Generation in Computer-Mediated Groups. // Management Science. 36, 6(1990), pp. 689-703. DOI: 10.1287/mnsc.36.6.689

[33] Plucker, J. A.; Beghetto, R. A.; Dow, G. T. Why Isn't Creativity More Important to Educational Psychologists? Potentials, Pitfalls, and Future Directions in Creativity Research. // Educational Psychologist. 39, 2(2004), pp. 83-96. DOI: 10.1207/s15326985ep3902_1

[34] Shah, J.; Smith, S. et al. Empirical studies of design ideation: alignment of design experiments with lab experiments. // In: ASME 2003 international conference on design theory and methodology, Chicago, 2003.

[35] Horn, I.; Salvendy, D. Product creativity: conceptual model, measurement and characteristics. // Theoretical Issues in Ergonomics Science. 7, 4(2006), pp. 395-412. DOI: 10.1080/14639220500078195

[36] Cropley, D.; Kaufman, J. Measuring Functional Creativity: Non-Expert Raters and the Creative Solution Diagnosis Scale. // Journal of Creative Behavior. 46, 2(2012), pp. 119-137. DOI: 10.1002/jocb.9

[37] Kudrowitz, B.; Wallace, D. Assessing the quality of ideas from prolific, early-stage product ideation. // Journal of Engineering Design. 24, 2(2013), pp. 120. DOI: 10.1080/09544828.2012.676633

[38] Statistički ljetopis Republike Hrvatske, Državni zavod za statistiku Republike Hrvatske, Zagreb, 2012.

[39] Cheng Long, Y.; Ling, Z.; Fan Rang, K. Study on innovation and management of the objective stage in product design. // Management. 10, 2(2005), pp. 99-109.

[40] IBM Global Business Services, (2006), Expanding the Innovation Horizon, The Global CEO Study 2006 http://www-935.ibm.com/services/us/gbs/bus/pdf $(8.10 .2014)$

\section{Authors' addresses}

Milan Stevanović, PhD, Research Associate,

University of Zagreb, Faculty of Mechanical Engineering and Naval Architecture, Ivana Lucica 5, 10000 Zagreb, Croatia mstevanovic@fsb.hr

Markot.tel d.o.o., Trg Kresimira Cosica 11, 10000 Zagreb, Croatia milan.stevanovic@inet.hr

\section{Dorian Marjanović, PhD, Full Professor,} Mario Štorga ${ }^{*}$, PhD, Associate Professor,

University of Zagreb, Faculty of Mechanical Engineering and Naval Architecture, Ivana Lucica 5, 10000 Zagreb, Croatia dorian@fsb.hr mario.storga@fsb.hr

* Guest Associate Professor, Lulea University of Technology, Department of Business Administration, Technology, and Social Sciences, Sweden

mario.storga@1tu.se 